\title{
Pengaruh Model Pembelajaran Team Assisted Individualization Berbantuan Asesmen Portofolio Terhadap Hasil Belajar IPA
}

\author{
Ni Putu Nopiyanti ${ }^{1}$, Ndara Tanggu Renda ${ }^{2}$, Ni Wayan Rati ${ }^{3}$ \\ 1,2,3 Jurusan Pendidikan Guru Sekolah Dasar, FIP \\ Universitas Pendidikan Ganesha \\ Singaraja, Indonesia \\ e-mail : niputunopiyanti888@gmail.com ${ }^{1}$, ndaratanggu.renda@undiksha.ac.id ${ }^{2}$, \\ niwayan_rati@undiksha.ac.id ${ }^{3}$
}

\begin{abstract}
Abstrak
Penelitian ini bertujuan untuk mengetahui perbedaan yang signifikan hasil belajar IPA siswa yang dibelajarkan dengan model Team Asisted Individualization berbantuan asesmen portofolio dan siswa yang dibelajarkan dengan pembelajaran konvensional pada siswa kelas III di SD Gugus III Kecamatan Sukasada Kabupaten Buleleng. Jenis penelitian ini adalah penelitian eksperimen semu menggunakan desain non-equivalent post test only control grup desain. Data hasil belajar IPA dikumpulkan menggunakan tes pilihan ganda. Data yang diperoleh dianalisis dengan menggunakan teknik analisis statistik deskriptif dan statistik inferensial yaitu uji-t. hasil analisis data yang diperoleh, yaitu (1) hasil belajar IPA siswa kelompok eksperimen dengan $M=23,70$, tergolong kriteria sangat tinggi, (2)hasil belajar IPA siswa kelompok control dengan $M=18,61$ tergolong kriteria tinggi, (3) hasil dari uji-t menunjukkan bahwa thitung $=4,11$ dan ttabel $=2,012$ (thitung $>$ ttabel). Dengan demikian dapat disimpulkan bahwa terdapat perbedaan yang signifikan hasil belajar IPA antara kelompok siswa yang dibelajarkan dengan model pembelajaran Team Asisted Individualization dan kelompok siswa yang dibelajarkan dengan pembelajaran konvensional pada siswa kelas III di SD Gugus III Kecamatan Sukasada Kabupaten Buleleng tahun pelajaran 2017/2018.
\end{abstract}

Kata-kata kunci: hasil belajar IPA, portofolio, TAI

\begin{abstract}
This study was purpose to know the significant differences on the result learning of science of students who were taught by the model of Asisted Individualization assisted by the assessment of the portfolio and students who were taught by conventional learning in third grade students in SD Gugus III Sukasada District, Buleleng Regency. The type of research was a quasi-experimental study using a non-equivalent design posttest only control design group. The result learning of science were collected using multiple choice tests. The data obtained were analyzed using descriptive and inferential statistical analysis technique, $t$-test. the result of data analysis obtained, that was (1) result of science learning of experiment group student with $M=23,70$, classified as very high criterion, (2) result of science study of control group student with $M=18,61$ classified high criterion, (3) the result of the $t$-test shows that thitung $=4.11$ and ttable $=2.012$ (tcount> ttable). Thus it can be concluded that there are significant differences in the result of science between groups of students who were taught by the learning model of Team Asisted Individualization and groups of students who were taught by conventional learning in third grade students at SD Gugus III Sukasada District, Buleleng District, in the academic year 2017/2018.
\end{abstract}

Keywords:learning result of science, portfolio, TAI 


\section{Pendahuluan}

Pendidikan memegang peranan penting dalam meningkatkan kualitas sumber daya manusia (SDM). Semakin tinggi tingkat pendidikan maka akan semakin baik pula kualitas sumber daya manusia (SDM). Untuk mencapai kualitas sumber daya manusia (SDM) yang berkualitas maka diperlukan pendidikan. Sesuai dengan pengertian pendidikan adalah usaha sadar dan terencana untuk mewujudkan suasana belajar dan proses pembelajaran yang bertujuan agar peserta didik secara aktif mengembangkan potensi dirinya untuk memiliki kekuatan spiritual, keagamaan, pengendalian diri, kepribadian kecerdasan, akhlak mulia, serta keterampilan yang diperlukan dirinya, masyarakat, bangsa dan negara.

$\mathrm{Di}$ jaman modern seperti saat ini dipenuhi dengan persaingan yang sangat ketat, oleh karna itu peserta didik perlu dibekali dengan berbagai keterampilan dan ilmu pengetahuan, salah satunya yaitu IImu Pengetahuan Alam (IPA). IImu Pengetahuan Alam bisa didapat siswa melalui pembelajaran IPA. Pembelajaran IPA merupakan hal yang sangat penting untuk dipelajari oleh peserta didik karena IPA berhubungan dengan cara penguasaan kumpulan pengetahuan yang berupa fakta, konsep-konsep atau prinsip-prinsip tetapi juga merupakan proses.

Hal ini sejalan dengan pendapat Nash (dalam Usman Samatowa, 2010:3), "IPA adalah suatu cara atau metode untuk mengamati alam". Nash juga menjelaskan bahwa cara IPA mengamati dunia ini bersifat analisis, lengkap, cermat, serta menghubungkannya antara satu fenomena dengan fenomena lain, sehingga keseluruhannya membentuk suatu perspektif yang baru tentang objek yang diamatinya. Hal ini sesuai dengan Tujuan pembelajaran IPA di SD berdasarkan Permendiknas Nomor 22 Tahun 2006 secara terperinci adalah: (1) memperoleh keyakinan terhadap kebesaran Tuhan Yang Maha Esa, (2) mengembangkan pengetahuan dan pemahaman konsep-konsep IPA yang bermanfaat, (3) mengembangkan rasa ingin tahu, sikap positif dan kesadaran tentang adanya hubungan yang saling mempengaruhi, (4) mengembangkan keterampilan proses untuk menyelidiki alam sekitar, memecahkan masalah dan membuat keputusan, (5) meningkatkan kesadaran untuk berperan serta dalam memelihara, menjaga dan melestarikan lingkungan alam (6) memperoleh bekal pengetahuan, konsep, dan keterampilan IPA sebagai dasar untuk melanjutkan pendidikan ke SMP.

Melalui pembelajaran IPA diharapkan siswa akan memperoleh hasil belajar yang maksimal. Hasil belajar IPA yaitu kemampuan yang diperoleh siswa setelah mengikuti pembelajaran IPA. Hal ini sejalan dengan pendapat Nawawi (dalam Susanto, (2013:5) menyatakan bahwa, "hasil belajar dapat diartikan sebagai tingkat keberhasilan siswa dalam mempelajari materi pelajaran di sekolah yang dinyatakan dalam skor yang diperoleh dari hasil tes mengenai sejumlah materi pelajaran tertentu". Berdasarkan hal tersebut, pembelajaran IPA sangat diperlukan untuk meningkatkan hasil belajar IPA siswa.

Namun pada kenyataannya hasil belajar IPA siswa masih rendah. Berdasarkan hasil wawancara yang telah dilakukan dengan guru-guru kelas III yang ada di Gugus III Kecamatan Sukasada Kabupaten Buleleng pada tanggal 15-16 Nopember 2017 diperoleh informasi mengenai masalah-masalah atau kendala-kendala yang dihadapi guru-guru dalam pembelajaran IPA. Dari hasil wawancara diperoleh informasi bahwa siswa di kelas malu untuk bertanya dan mengungkapkan pendapatnya tentang masalah yang mereka alami atau temui saat pembelajaran IPA karena siswa merasa takut jika pendapat yang disampaikannya salah sehingga siswa menjadi pasif saat pembelajaran, dan waktu yang digunakan tidak cukup untuk menjelaskan materi pembelajaran. Selain itu juga dilakukan observasi pada tanggal 28-30 Nopember di SD Gugus III Kecamatan Sukasada mengenai pelaksanaan pembelajaran IPA di kelas kepada guru-guru di kelas III. Pada saat melakukan observasi diperoleh kenyataan bahwa pembelajaran masih berpusat pada guru sehingga siswa menjadi pasif pada saat pembelajaran IPA, guru lebih dominan menggunakan metode ceramah pada saat pembelajaran sehingga siswa menjadi pasif, dan guru kurang menggunakan media yang menarik pada saat pembelajaran sehingga pembelajaran menjadi kurang menarik yang mengakibatkan siswa menjadi mengantuk, bosan dan pembelajaran menjadi tidak kondusif. Hasil wawancara dan observasi tersebut memberikan gambaran bahwa kegiatan pembelajaran IPA didominasi oleh guru (teacher centered) dan kurangnya motivasi belajar siswa.

Berdasarkan hasil pencatatan dokumen diketahui bahwa nilai rata-rata hasil belajar kognitif IPA siswa di kelas III di SD Gugus III Kecamatan Sukasada berada pada interval 57,664,3. Jika dikonversikan terhadap skala penilaian acuan patokan (PAP) (dalam Agung, 2014:251), interval tersebut berada pada kategori rendah. Hal ini menandakan bahwa nilai rata- 
rata UAS IPA siswa kelas III di Gugus III Kecamatan Sukasada dapat diklasifikasikan hasil belajar masih rendah.

Kenyataan di atas terjadi dikarenakan beberapa hal, salah satunya yaitu guru kurang menggunakan model pembelajaran yang tepat dan sesuai dengan materi pembelajaran sehingga pembelajaran menjadi kurang menarik. Oleh karena itu, dalam hal ini guru hendaknya merancang sebuah proses pembelajaran agar lebih menarik, sehingga siswa merasa senang dan tidak mudah jenuh selama mengikuti pembelajaran. Selain itu, pembelajaran yang menarik dapat menjadikan siswa lebih aktif secara fisik dan mental, sehingga siswa dapat menguasai materi dengan baik yang akan berdampak pula pada peningkatan hasil belajar siswa. Salah satu upaya yang dapat dilakukan untuk meningkatkan hasil belajar siswa yaitu dengan menggunakan model pembelajaran Team Assisted Individualization (TAI). Model pembelajaran ini akan membuat siswa menjadi lebih aktif karena siswa akan bekerja bersama-sama dengan kelompoknya, karena dengan menggunakan model pembelajaran Team Assisted Individualization (TAI) diharapkan siswa dapat meningkatkan hasil belajar IPA. Model Team Assisted Individualization (TAI) adalah suatu model pembelajaran yang memberikan kesempatan kepada siswa untuk berpikir, merespon, dan saling membantu satu satu sama lain, siswa dituntut untuk dapat berdiskusi bersama-sama dengan anggota kelompoknya secara aktif dan saling bekerja sama dalam menyelesaikan suatu permasalahan terkait materi yang diberikan oleh guru. Model pembelajaran ini secara langsung melibatkan siswa dalam pembelajaran. Hal ini sesuai dengan yang dikatakan Slavin (dalam Huda, 2013:200), "model Team Assisted Individualization (TAl) merupakan sebuah program pedagogik yang berusaha mengadaptasi pembelajaran dengan perbedaan individual siswa secara akademik". Pengembangan TAI dapat mendukung praktik-praktik ruang kelas, seperti pengelompokkan siswa, pengelompokkan kemampuan di dalam kelas, pengajaran terprogram, dan pengajaran berbasis komputer.

Model pembelajaran Team Assisted Individualization (TAl) akan lebih efektif jika penggunaan model Team Assisted Individualization (TAl) dipadukan dengan asesmen portofolio sebagai alat bantu dalam melakukan penilaian. Dengan demikian maka hasil belajar yang diperoleh siswa akan optimal karena asesmen portofolio adalah penilaian secara keseluruhan yang dilakukan oleh guru kepada siswa dari awal pembelajaran sampai akhir pembelajaran melalui pengumpulan dokumen berupa tugas-tugas kelas, kerja keterampilan, dan semua hasil kerja peserta didik. Hal ini sesuai dengan yang dikatakan oleh Marhaeni (dalam Koyan, 2011:82), "Asesemen portofolio adalah suatu prosedur pengumpulan informasi mengenai perkembangan dan kemampuan peserta didik melalui portofolionya". Dengan demikian jika model pembelajaran Team Assisted Individualization (TAI) dipadukan dengan asesmen portofolio akan menghasilkan penilaian yang optimal sehingga memungkinkan hasil belajar siswa akan maksimal. Dalam menerapkan

Model pembelajaran TAI berbantuan asesmen portofolio dapat menumbuhkan minat siswa dalam belajar serta tanggung jawab dalam mengerjakan tugas-tugas baik secara kelompok maupun individu yang nantinya berpengaruh terhadap hasil belajar IPA siswa.

Berdasarkan uraian di atas, maka penting dilakukan penelitian eksperimen yang berjudul "Pengaruh Model Pembelajaran Team Assisted Individualization Berbantuan Asesmen Fortofolio Terhadap Hasil Belajar IPA Siswa Kelas III SD Semester Genap di Gugus III Kecamatan Sukasada Tahun Pelajaran 2017/2018".

Adapun tujuan penelitian ini adalah untuk menguji bagaimana pengaruh model pembelajaran Team Assisted Individualization Berbantuan Asesmen Fortofolio Terhadap Hasil Belajar IPA Siswa Kelas III SD Semester Genap di Gugus III Kecamatan Sukasada Tahun Pelajaran 2017/2018.

\section{Metode}

Penelitian ini dilaksanakan di Sekolah Dasar Gugus III Kecamatan Sukasada Kabupaten Buleleng. Penelitian ini dilaksanakan pada semester 2 tahun pelajaran 2017/2018. Jenis penelitian ini adalah eksperimen semu (quasi eksperimen). Desain penelitian ini menggunakan desain penelitian eksperimen non-equivalent post test only control group design. 
Tabel 1. Rancangan Penelitian

\begin{tabular}{lcc}
\hline Kelas & Perlakuan & Post test \\
\hline Eksperimen & $\mathrm{X}_{1}$ & $\mathrm{O}_{1}$ \\
\hline Kontrol & - & $\mathrm{O}_{2}$ \\
\hline
\end{tabular}

Keterangan

$\mathrm{X} 1$ = perlakuan model pembelajaran Team Assisted Individualization (TAI)

berbantuan asesmen portofolio

= pembelajaran konvensional

$\mathrm{O} 1$ = post-test terhadap kelompok eksperimen

$\mathrm{O} 2$ = post-test terhadap kelompok control

Dengan populasi penelitian ini sebanyak 135 orang siswa kelas III di SD Gugus III Kecamatan Sukasada Kabupaten Buleleng yang berjumlah 7 kelas. Untuk mengetahui kesetaraan kemampuan akademik pada populasi penelitian maka dilakukan uji ANAVA terhadap data hasil belajar IPA pada ranah kognitif siswa kelas III pada semester 1 (ganjil).

Berdasarkan hasil perhitungan uji kesetaraan ANAVA A pada taraf signifikansi $5 \%$ diperoleh. Berdasarkan hasil uji kesetaraan yang dilakukan diperoleh hasil bahwa, hasil belajar IPA siswa kelas III SD di Gugus III Kecamatan Sukasada setara. Pengambilan sampel dalam penelitian ini menggunakan teknik random sampling dengan cara undian. Hasil pengundian tersebut adalah SD N 1 Padangbulia terpilih sebagai kelompok eksperimen dan SD $\mathrm{N} 2$ Padangbulia sebagai kelompok kontrol. Kelas eksperimen diberikan perlaku pembelajaran dengan model pembelajaran Team Assisted Individualization berbantuan asesmen portofolio dan kelas kontrol tidak diberikan perlakuan pembelajaran sehingga dilaksanakan pembelajaran sebagaimana biasanya.

Koefisien validitas isi tes kemampuan hasil belajar IPA ranah kognitif berdasarkan hasil perhitungan sebesar 1,00 . Apabila nilai tersebut dikonversikan terhadap kriteria validitas isi, maka koefisien validitas isi tes hasil belajar IPA berada pada rentangan 0,800-1,00 atau tergolong sangat tinggi.

Pengujian validitas butir tes dilakukan dengan menggunakan bantuan program Microsoft Office Excel for Windows. Dari 40 butir soal yang diuji cobakan, terdapat 33 soal yang valid dan 7 butir soal tidak valid.

Pengujian reliabilitas tes dilakukan dengan menggunakan bantuan program Microsoft Office Excel for Windows. Berdasarkan hasil uji reliabilitas tes, diperoleh koefisien reliabilitas tes sebesar 0,67 dari 40 soal yang diuji cobakan. Hal ini berarti, tes yang diuji termasuk ke dalam kriteria reliabilitas tinggi.

Pengujian taraf kesukaran tes dilakukan dengan menggunakan Microsoft Office Excel for Windows. Berdasakan hasil uji tingkat kesukaran tes diperoleh $\mathrm{Pp}=0,40$ sehingga perangkat tes yang digunakan termasuk kriteria sedang.

Berdasarkan hasil uji daya beda tes yang dibantu dengan program Microsoft Office Excel for Windows, diperoleh $\mathrm{Dp}=0,42$ sehingga perangkat tes yang digunakan termasuk kriteria baik.

Penelitian ini melibatkan dua variabel yaitu variabel bebas dan variabel terikat. Variabel bebas dalam penelitian ini yaitu Team Assisted Individualization berbantuan asesmen portofolio yang diterapkan pada kelompok eksperimen dan bukan dengan model pembelajaran Team Assisted Individualization yang diterapkan pada kelompok kontrol, sedangkan variabel terikatnya adalah hasil belajar IPA.

Dalam penelitian ini teknik pengumpulan data yang digunakan adalah metode tes. Jenis instrumen berupa tes objektif dalam bentuk pilihan ganda. Data yang dianalisis dalam penelitian ini adalah hasil belajar IPA yang dikumpulkan melalui tes pilihan ganda. Tes tersebut telah diuji coba lapangan sehingga teruji tes tersebut kemudian diuji coba lapangan untuk mencari validitas, reliabilitas, taraf kesukaran, dan daya bedanya. Hasil tes uji coba lapangan tersebut selanjutnya diberikan kepada siswa kelas eksperimen dan kontrol sebagai post-test

Analisis data yang digunakan dalam penelitian ini yaitu analisis statistik deskriptif dan data dianalisis dengan menghitung nilai mean, median, modus, standar deviasi, varian, skor maksimum, skor minimum.

Dalam penelitian ini data disajikan dalam bentuk kurva polygon. Sedangkan teknik yang digunakan untuk menguji hipotesis adalah uji-t (polled varians). Untuk bisa melakukan uji hipotesis, ada beberapa persyaratan yang harus dipenuhi dan perlu dibuktikan. Persyaratan 
yang dimaksud yaitu (data yang dianalisis harus berdistribusi normal, (data yang dianalisis harus bersifat homogen, untuk dapat membuktikan dan memenuhi persyaratan tersebut, maka dilakukan uji prasyarat analisis dengan melakukan uji normalitas dan uji homogenitas

\section{Hasil dan Pembahasan}

Data penelitian ini adalah skor hasil belajar IPA siswa yang belajar dengan model pembelajaran Team Assisted Individualization berbantuan asesmen portofolio pada kelompok eksperimen dan kelompok siswa yang belajar dengan pembelajaran konvensional. Setelah dilakukan penelitian diperoleh hasil belajar IPA siswa kelompok eksperimen dan kelompok kontrol. Mean, median, modus, varian, standar deviasi, skor minimum, skor maksimum hasil belajar siswa kelas III SD N 1 Padangbulia dan SD N 2 Padangbulia. Deskripsi data hasil belajar IPA siswa yang memaparkan mean, median, modus, standar deviasi, varians dapat dilihat pada Tabel 2

Tabel 2. Deskripsi hasil belajar IPA

\begin{tabular}{ccc}
\hline Data Statistik & \multicolumn{2}{c}{ Hasil Belajar IPA } \\
\cline { 2 - 3 } & Kelompok Eksperimen & Kelompok kontrol \\
\hline Mean & 23,70 & 18,61 \\
\hline Median & 24,44 & 18,50 \\
\hline Modus & 24,70 & 17,75 \\
\hline Varians & 20,71 & 17,65 \\
\hline Standar Deviasi & 4,55 & 4,20 \\
\hline Skor Minimal & 12 & 10 \\
\hline Skor Maksimal & 28 & 25 \\
\hline
\end{tabular}

Berdasarkan Tabel di atas dapat dikemukakan bahwa kelompok eksperimen yang belajar menggunakan model pembelajaran Team Assisted Individualization memiliki mean $(M)=23,70$ median $(M d)=24,44$ modus $(M o)=24,70$ varians $\left(s^{2}\right)=20,71$ dan standar devias $=$ 4,55 skor minimal= 12 dan skor maksimal=28. Nilai mean, median, modus disajikan dalam bentuk kurva polygon, tujuannya untuk menafsirkan sebaran data hasil belajar IPA pada kelompok eksperimen. Hubungan antara mean, median, dan modus dapat digunakan untuk menentukan kemiringan kurva polygon distribusi frekuensi. Grafik data hasil belajar eksperimen dapat dilihat pada gambar 1 .

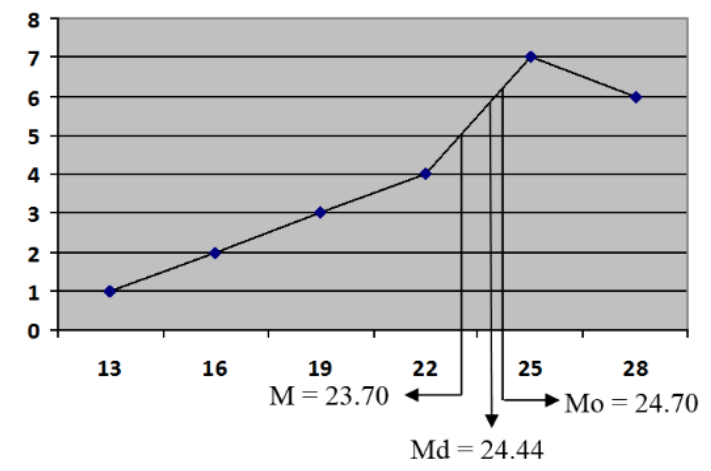

Gambar 1 Grafik Data Hasil Belajar Kelompok Eksperimen

Berdasarkan grafik polygon di atas, diketahui bahwa pada kelompok eksperimen nilai modus lebih besar dari median dan median lebih besar dari mean (Mo $>M d>M$ ), sehingga kurva yang terbentuk adalah kurva juling negatif yang artinya skor cenderung tinggi. Jika dikonversi ke dalam pedoman penetapan kategori hasil belajar IPA kelompok eksperimen berada pada kategori sangat tinggi. Sedangkan pada kelompok kontrol dapat dapat dideskripsikan mean (M), median (Md), modus (Mo), varians, dan standar deviasi (s) dari data hasil belajar IPA kelompok kontrol. Pada kelompok kontrol memiliki mean $(\mathrm{M})=18,61$ median $(\mathrm{Md})=18,50$ modus $(\mathrm{Mo})=17,75$ varians $\left(\mathrm{s}^{2}\right)=17,65$ dan standar deviasi $(\mathrm{s})=4,20$, skor minimal $=10$, skor maksimal $=25$. Data hasil belajar kelompok kontrol dapat disajikan ke dalam 
grafik data hasil belajar kelompok kontrol. Grafik data hasil belajar kontrol dapat dilihat pada gambar 2.

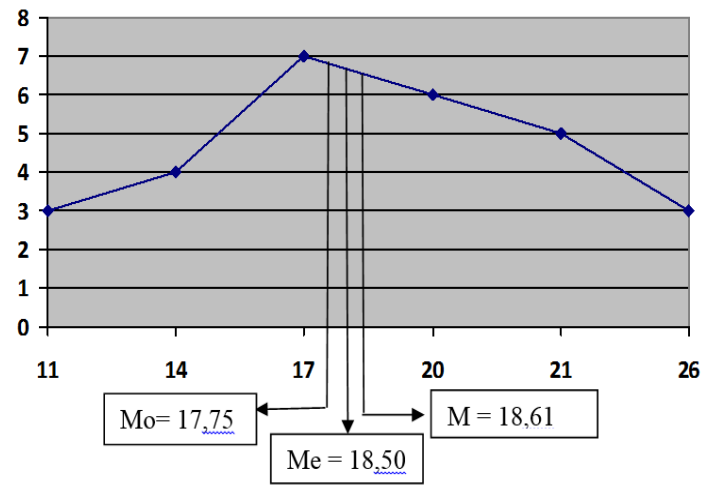

Gambar 2 Grafik Data Hasil Belajar Kelompok Kontrol

Berdasarkan grafik polygon di atas, maka dapat diketahui modus lebih kecil dari median dan median lebih kecil dari mean $(\mathrm{Mo}<\mathrm{Md}<\mathrm{M}$ ), sehingga kurva di atas adalah kurva juling positif yang artinya skor cenderung rendah. Jika dikonversi ke dalam pedoman penetapan kategori hasil belajar IPA kelompok eksperimen berada pada kategori tinggi.

Dengan kata lain, model pembelajaran Team Assisted Individualization memiliki ratarata skor hasil belajar IPA lebih tinggi dibandingkan dengan pembelajaran konvensional. Sebelum melakukan uji hipotesis maka harus dilakukan beberapa uji prasyarat, uji prasyarat meliputi uji normalitas dan uji homogenitas varians. Uji normalitas data dilakukan terhadap data hasil belajar IPA kelompok eksperimen dan kontrol. Berdasarkan hasil perhitungan dengan menggunakan rumus chi-kuadrat, diperoleh $x^{\text {2hit }}$ hasil hasil post-test kelompok eksperimen adalah 6,20 dan $x^{2 \text { tab }}$ dengan taraf signifikansi $5 \%$ dan $\mathrm{db}=3$ adalah 7,815. Hal ini berarti, ${ }^{2}$ hit hasil post-test kelompok eksperimen lebih kecil dari $x^{2 \text { tab }}\left(x^{2 \text { hit }}<x^{2 \text { tab }}\right)$, sehingga data hasil posttest kelompok eksperimen berdistribusi normal. Sedangkan $x^{2}$ hit hasil post-test kelompok kontrol adalah 3,65 dan $x^{2}$ tab dengan taraf signifikansi $5 \%$ dan $\mathrm{db}=3$ adalah 7,815 . Hal ini berarti $x^{2}$ hit hasil hasil post-test kelompok kontrol lebih kecil dari $x^{2}$ tabel $\left(x^{2}\right.$ hitung $<x^{2}$ tabel $)$, sehingga data hasil post-test kelompok kontrol berdistribusi normal. Setelah melakukan uji normalitas maka dilanjutkan dengan uji homogenitas. Uji homogenitas dilakukan untuk mengetahui data bersifat homogenitas dihitung dengan cara membagi varians terbesar varians terkecil. Uji yang dilakukan adalah uji $F$ dengan kriteria data homogeny jika $F$ hit $<F$ tab. Berdasarkan hasil uji, diketahui $\mathrm{F}_{\text {hit }}$ hasil post-test keompok eksperimen dan kelompok kontrol adalah 1,17, sedangkan $\mathrm{F}_{\text {tab }}$ dengan $\mathrm{db}_{\text {pembilang }}=22 \mathrm{db}_{\text {penyebut }}=27$, dan taraf signifikansi $5 \%$ adalah 2,0115. Hal ini berarti, varians data hasil post-test kelompok eksperimen dan kelompok kontrol adalah homogen.

Setelah melakukan analisis deskripsi dan uji prasyarat, maka dilanjutkan dengan melakukan uji hipotesis. Hipotesis penelitian yang diuji adalah terdapat pengaruh model pembelajaran Team Assisted Individualization berbantuan asesmen portofolio terhadap hasil belajar IPA siswa kelas III semester genap di SD Gugus III Kecamatan Sukasada Kabupaten Buleleng Tahun Ajaran 2017/2018.

Pengujian hipotesis tersebut dilakukan dengan menggunakan uji-t sampel independent (tidak berkorelasi) dengan rumus polled varians dengan kriteria $\mathrm{H}_{0}$ tolak jika $\mathrm{t}_{\text {hitung }}>\mathrm{t}_{\text {tabel }}$ dan $\mathrm{H}_{0}$ diterima jika $\mathrm{t}_{\text {nitung }}>\mathrm{t}_{\text {tabel }}$. $\mathrm{H}_{0}$ jika $\mathrm{t}_{\text {nitung }}>\mathrm{t}_{\text {tabel }}$ dimana $\mathrm{t}_{\text {tab }}$ diperoleh dari tabel distribusi $t$ pada taraf signifikansi $5 \%$ dengan derajat kebebasan $\mathrm{db}=\mathrm{n} 1+\mathrm{n} 2-2$. Rangkuman hasil perhitungan uji-t antara kelompok eksperimen dan kelompok kontrol disajikan pada Tabel 3 sebagai berikut.

Tabel 3. Rangkuman Hasil Perhitungan Uji-t

\begin{tabular}{|c|c|c|c|c|c|}
\hline Data Kelompok & $\mathbf{N}$ & $\mathbf{X}$ & $s^{2}$ & $t_{\text {hit }}$ & $t_{\text {tabel }}(t . s 5 \%)$ \\
\hline Eksperimen & 23 & 23,70 & 20,71 & 4,11 & 2,012 \\
\hline Kontrol & 28 & 18,61 & 17,65 & & \\
\hline
\end{tabular}

Berdasarkan Tabel hasil perhitungan uji-t di atas diperoleh thit sebesar 4,11 dan ttabel = 2,012 untuk $\mathrm{db}=49$ pada taraf signifikansi $5 \%$. Berdasarkan kriteria pengujian, karena thitung 
$>\mathrm{t}$ tabel maka $\mathrm{HO}$ ditolak dan $\mathrm{Hi}$ diterima. Artinya, terdapat perbedaan hasil belajar IPA yang signifikan hasil belajar IPA antara kelompok siswa yang belajar dengan menggunakan model pembelajaran Team Assisted Individualization berbantuan asesmen portofolio dan kelompok siswa yang belajar dengan menggunakan pembelajaran konvensional pada siswa kelas III SD Gugus III Kecamatan Sukasada Kabupaten Buleleng Tahun Pelajaran 2017/2018.

PEMBAHASAN

Pembahasan hasil penelitian dan pengujian hipotesisi menguraikan tentang analisis deskriptif dan analisis statistic yang menckup variabel bebas dan variabel terikat. Variabel bebas pada penelitian ini yaitu model pembelajaran Team Assisted Individualization dan variabel terikat yaitu hasil belajar IPA. Pembahasan hasil analisis data pada hipotesis yang diajukan dipaparkan sebagai berikut.

Model pembelajaran Team Assisted Individualization berbantuan asesmen portofolio sangat berpengaruh terhadap hasil belajar IPA siswa. Karena dengan pembelajaran menggunakan model pembelajaran Team Assisted Individualization berbantuan asesmen portofolio hasil belajar IPA siswa menjadi lebih baik, hal ini menunjukkan bahwa terdapat pengaruh yang positif model pembelajaran Team Assisted Individualization berbantuan asesmen portofolio terhadap hasil belajar IPA siswa. Berdasarkan analisis data menggunakan uji-t di atas, diketahui thitung $=4,11$ dan ttabel $=2,012(\mathrm{db}=49$ dan taraf signifikansi $5 \%)=$ 2,012. Hasil perhitungan tersebut menunjukkan bahwa thitung lebih besar dari ttabel (t hitung > t tabel), sehingga hasil penelitian adalah signifikan. Hal ini berarti, terdapat perbedaan yang signifikan hasil belajar IPA antara siswa yang mengikuti pembelajaran dengan model pembelajaran Team Assisted Individualization berbantuan asesmen portofolio dan siswa yang mengikuti pembelajaran tidak menggunakan model pembelajaran Team Assisted Individualization.

Adanya perbedaan yang signifikan menunjukkan bahwa penerapan model pembelajaran Team Assisted Individualization berpengaruh terhadap hasil belajar IPA siswa. Untuk mengetahui besarnya pengaruh antara model pembelajaran Team Assisted Individualization dan tidak menggunakan model pembelajaran Team Assisted Individualization, dapat dilihat dari nilai rata-rata hasil belajar IPA antara kedua kelas tersebut. Rata-rata hasil belajar IPA kelas eksperimen adalah 23,70, sedangkan, rata-rata hasil belajar IPA kelas kontrol adalah 18,61. Hal ini berarti, rata-rata skor kelas eksperimen lebih besar dari rata-rata skor kelas kontrol (Meksperimen > Mkontrol).

Perbedaan yang signifikan antara siswa yang mengikuti pembelajaran dengan model pembelajaran Team Assisted Individualization dan siswa yang mengikuti pembelajaran tidak menggunakan model pembelajaran Team Assisted Individualization disebabkan karena beberapa faktor yaitu sebagai berikut.

Pertama, perbedaan perlakuan pada langkah-langkah dan proses pembelajaran. Pembelajaran dengan model pembelajaran Team Assisted Individualization menekankan aktivitas siswa melalui delapan tahapan yaitu tahap placement test (tes awal), tahap teams (tim), teaching group (memberikan materi), student creative (memberikan persepsi), team study (belajar kelompok), fact test (tes-tes kecil), team score and team recognition (skor dan penghargaan), dan whole-class units (menyajikan kembali materi). Dengan model pembelajaran Team Assisted Individualization siswa dituntut untuk dapat bekerja sama dengan kelompoknya dalam menyelesaikan tugas yang diberikan dan saling menghargai pendapat antara satu siswa dengan siswa lainnya di dalam kelompok dan siswa dapat menghargai pendapat siswa lainnya. Hal ini sejalan dengan pendapat atau teori yang disampaikan oleh Suyitno (dalam Shoimin, 2014:200), menyatakan bahwa "dalam pembelajaran TAl, siswa ditempatkan dalam kelompokkelompok kecil (4 sampai 5 siswa) yang heterogen dan selanjutnya diikuti dengan pemberian bantuan secara individu bagi siswa yang memerlukannya. Dengan pembelajaran kelompok, diharapkan para siswa dapat meningkatkan pikiran kritisnya, kreatif, dan menumbuhkan rasa sosial yang tinggi.

Kedua, model pembelajaran Team Assisted Individualization berbantuan asesmen portofolio menyebabkan siswa dapat memahami berbagai pengetahuan dalam pelajaran IPA melalui tugas-tugas yang diberikan sehingga siswa lebih mudah memahami materi pelajaran yang diberikan oleh guru. Hal ini sesuai dengan teori yang disampaikan oleh Marhaeni (dalam Koyan, 2011:82) menyatakan asesemen portofolio adalah suatu prosedur pengumpulan informasi mengenai perkembangan dan kemampuan peserta didik melalui portofolionya. Portofolio tersebut dapat berupa tugas-tugas, hasil ulangan, dan lain-lain. karena melalui tugastugas siswa dapat lebih mudah memahami materi pelajaran. 
Ketiga, model pembelajaran Team Assisted Individualization berbantuan asesmen portofolio sesuai diterapkan dalam pembelajaran IPA, karena dalam pembelajaran IPA terdapat berbagai pengetahuan yang dapat dikemas dalam berbagai bentuk tugas sehingga siswa lebih mudah dipahami oleh siswa.

Pada saat proses pembelajaran menggunakan model pembelajaran Team Assisted Individualization berbantuan asesmen portofolio siswa terlihat sangat antusias dalam mengikuti pembelajaran, siswa juga aktif pada saat pembelajaran, karena dengan menggunakan model pembelajaran Team Assisted Individualizatiom berbantuan asesmen portofolio siswa dapat bertukar pikiran atau pendapat dengan siwa lainnya di dalam kelompok sehingga pembelajran menjadi lebih menyenangkan.

Pembelajaran dengan berbantuan asesmen portofolio akan mempermudah siswa dalam memahami materi pelajaran melalui tugas-tugas yang diberikan oleh guru. Karena siswa dapat memahami materi pelajaran melalui tugas-tugas yang dikerjakan oleh siswa. Karena asesmen portofolio adalah penilaian yang dilakukan oleh guru melalui pengumpulan tugas-tugas yang dikerjakan oleh siswa mulai dari awal pembelajaran sampai pembelajaran selesai. Hal ini sesuai dengan pendapat yang disampaikan oleh Senada dengan Salvia dan Ysseldyke (dalam Koyan, 2011:82) menyatakan bahwa, "portofolio adalah sekumpulan hasil karya peserta didik yang dapat menunjukkan apa yang bisa dilakukan oleh peserta didik tersebut". Kumpulan dokumen tersebut, berupa tugas-tugas kelas, draf, audio tapes, daftar buku yang telah dibaca, videotapes, hasil ulangan, check list, journal, penyelesaian projek, kerja keterampilan, dan semua hasil kerja peserta didik, termasuk evaluasi diri.

Hasil penelitian tersebut didukung oleh temuan beberapa penelian sebelumnya yang dilakukan oleh Ratnaningsih Indriani (2016) menunjukkan bahwa terdapat pengaruh penggunaan model pembelajaran kooperatif tipe Team Assisted Individualizatiom (TAI) terhadap belajar mata pelajaran IPS di kelas eksperimen. Adapun rata-rata nilai yang didapat oleh kelas eksperimen yaitu 79,79 sedangkan hasil belajar kelas kontrol adalah 69,08.

Hasil penelitian yang dilakukan oleh Putu Yuny Wulandari (2014) menunjukkan bahwa terdapat perbedaan yang signifikan hasil belajar IPS antara siswa yang mengikuti model pembelajaran kooperatif tipe TAl dan siswa yang mengikuti model pembelajaran konvensional. Ini terlihat dari nilai rata-rata yang didapat oleh kelas eksperimen yaitu 80, 25 sedangkan hasil belajar pada kelas kontrol adalah 65,50. Berdasarkan pemaparan di atas dapat ditarik kesimpulan bahwa model pembelajaran Team Assisted Individualization berbantuan asesmen portofolio berpengaruh positif terhadap hasil belajar IPA. Selain untuk meningkatkan hasil belajar siswa, melalui model pembelajaran Team Assisted Individualization siswa kelas III di SD Gugus III khususnya siswa kelas III di SD N 1 Padangbulia semakin mampu untu memahami suatu materi, mampu mendiskusikan materi bersama orang lain, dan mampu menyampaikan pendapat kepada orang lain. Artinya, terdapat pengaruh yang signifikan model pembelajaran Team Assisted Individualizatiom berbantuan asesmen portofolio terhadap hasil belajar IPA siswa kelas III Semester Genap di SD Gugus III Kecamatan Sukasada Kabupaten Buleleng Tahun Ajaran 2017/2018

\section{Simpulan dan Saran}

Berdasarkan hasil penelitian dan pembahasan di atas, dan hasil analisis data menggunakan uji-t di atas, diketahui thitung $=4,11$ dan ttabel $=2,012(\mathrm{db}=49$ dan taraf signifikansi $5 \%$ ) $=2,012$.

Hasil perhitungan tersebut menunjukkan bahwa thitung lebih besar dari ttabel ( $t$ hitung $>t$ tabel), sehingga hasil penelitian adalah signifikan. Sehingga dapat disimpulkan bahwa terdapat perbedaan yang signifikan hasil belajar IPA antara kelompok siswa yang dibelajarkan dengan model Pembelajaran Team Assisted Individualization berbantuan asesmen portofolio dan kelompok siswa yang dibelajarkan dengan pembelajaran konvensional. Dengan demikian penerapan model pembelajaran Team Assisted Individualization berbantuan asesmen portofolio memberikan pengaruh positif terhadap hasil belajar IPA pada siswa kelas III semester genap di SD Gugus III Kecamatan Sukasada Kabupaten Buleleng Tahun Ajaran 2017/2018.

Saran yang dapat disampaikan berdasarkan penelitian yang telah dilakukan adalah sebagai berikut. 1) bagi siswa kelas III SD N 1 Padangbulia agar lebih fokus dan aktif dalam proses pembelajaran untuk dapat meningkatkan hasil belajar pada mata pelajaran IPA. 2) bagi guru dapat dijadikan acuan dalam memilih dan mengembangkan model pembelajaran inovatif dan dinamis sesuai dengan materi yang diajarkan, karakteristik siswa, serta tujuan 
pembelajaran yang ingin dicapai. Selain itu penerapan suatu model pembelajaran yang inovatif diharapkan dapat meningkatkan profesionalisme guru dalam mengelola pebelajaran khususnya pada mata pelajaran IPA. 3) bagi kepala sekolah dapat dijadikan pedoman dalam pengambilan kebijakan untuk memperbaiki kualitas pembelajaran disekolah dengan menggunakan model pembelajaran yang tepat untuk meningkatkan kualitas pendidikan di sekolah. 4) Bagi peneliti lain yang berminat untuk menggunakan hasil penelitian ini sebagai salah satu acuan kepustakaan untuk melakukan penelitian pada variabel yang sama maupun yang berbeda.

\section{Daftar Pustaka}

Asriningsih, Komang. 2014. Pengaruh Model Pembelajaran Kooperatif Tipe Team Assisted Individualization (TAI) Terhadap Hasil Belajar IPA Siswa Kelas IV SD Gugus V Kecamatan Banjar Tahun Pelajaran 2013/2014. Jurnal Mimbar PGSD Universitas Pendidikan Ganesha. Volume 2, Nomor 1.

Hadinata, Md Sukma. 2013. Pengaruh Model Pembelajaran Team Assisted Individualization (TAI) Terhadap Prestasi Belajar IPS Kelas IV SD Gugus 4 Bondalem Kecamatan Tejakula Tahun Pelajaran 2012/2013. Universitas Pendidikan Ganesha

Indriani, Ratnaningsih. 2016. Pengaruh Model Team Assisted Individualization (TAI) Terhadap Hasil Belajar IPS Kelas V SD Negeri Jurugentong Tahun Pelajaran 2015/2016. Universitas Negeri Yogyakarta

Koyan, I Wayan. 2011. Asesmen Dalam Pendidikan. Singaraja: Universitas Pendidikan Ganesha

Koyan, I Wayan. 2012. Statistik Pendidikan Teknik Analisis Data Kuantitatif. Singaraja: Undiksha

Susanto, Ahmad. 2013. Teori Belajar dan Pembelajaran di Sekolah Dasar. Jakarta: Kencana Prenadamedia Group.

Undang-Undang Refublik Indonesia Nomor 20 Tahun 2003 tentang Sistem Pendidikan Nasional. 2003. Jakarta: Kementrian Pendidikan Nasional

Wulandari, Putu Yuny. 2014. Pengaruh Penerapan Model Pembelajaran Kooperatif Tipe Team Acelerated Instruction (TAI) Terhadap Hasil Belajar IPS Siswa Kelas V SD Gugus VIII Kedewatan Kecamatan Ubud Gianyar Tahun Pelajaran 2013/2014. Jurnal Mimbar PGSD Universitas Pendidikan Ganesha. Volume 2, Nomor $1 .$. 